\title{
Effect of Corporate Governance Practices on Financial Performance of Listed Agricultural Firms in The Nairobi Securities Exchange, Kenya
}

\author{
Miriam K. Ngwenze*, Morris Irungu Kariuki** \\ *MBA Student, University of Nairobi. \\ **Lecturer, Department of Finance and Accounting, University of Nairobi.
}

\begin{abstract}
The aim of this research was to determine the influence of corporate governance practices on financial performance in listed agricultural companies in Kenya. The corporate governance practices included board of directors' composition and size, independence of board and audit committees. The researcher used a descriptive correlation research design to determine the relationship between corporate governance practices and financial performance. The population comprised of all the seven firms that were listed in the Nairobi Securities Exchange (NSE) in the period 2012-2016. The data set comprised of secondary data collected from annual reports. A multiple regression model of financial performance against corporate governance practices was applied. It was found that some companies had violated the Capital Market Authority (CMA) Act threshold of three directors in the audit committee while other had poor board composition. Also breached was the benchmark set by the CMA Act for the independence of directors. The study established that corporate governance practices have no significant influence on ROE and ROA of listed agricultural firms in Kenya. However, it has significant influence on debt equity ratio. The findings concur with previous evidence from empirical studies on corporate governance, indicating that adoption of the various corporate governance practices by listed agricultural firms plays a part in the improvement of their performance financially.
\end{abstract}

Keywords: Corporate governance, financial performance, board size, board composition, audit committee and board independence,

\section{Introduction}

The term governance is derived from the latin word gubernare, meaning to steer. It usually applies to the steering of a ship. Thus, this implies that corporate governance involves the function of direction rather than control [1]. Corporate Governance has been defined as the control of management for best interests of the company, which include accountability to shareholders who elect directors and auditors. Corporate governance can also be defined as accountability to providers of capital [1,2]. Corporate governance is an essential feature for the survival of companies and it is a keystone used by these organisations to achieve their goals. The concept of corporate governance covers such a vast area so that there is not a single definition entailing all facets but each definition reflects a different aspect of the concept. In short, corporate governance is a set of processes, customs, rules and regulations which determines the running of an organisation towards its objective. Hence, corporate governance aims at managing a firm to generate profit and wealth so that each group associated to it, is treated in the best way [3].The issues of corporate government have become more visible and also the focus by both business leaders and regulators across the globe today. This is because corporate governance had received lack-lustre attention from corporate bodies globally for a considerable length of time [4].

The desertion of corporate governance policies eventually led to the recent global high profile corporate failures. For example, HIH insurance and One-Tel from Australia were among the failed corporate bodies. Other includes the Maxwell Communications Corporation and Bank of Credit and Commerce International in the United Kingdom; WorldCom and Enron in United States of America and Parmalat from Italy. All these corporate failures have been accredited to meagre corporate governance practices [5]. In Kenya, there have been several corporate failures involving public organizations such as Pan African Paper Mills in Webuye, Kisumu Cotton Mills, Rift Valley Textiles, Kenya Planters Cooperative Union, Miwani sugar factory and many other privately owned entities. The most recent business failures are financial institutions namely Chase and Imperial banks. These business failures raise some essential questions such as management elegance, audit objectivity, ethics, professionalism, disclosures, personal accountability and conflict of interest. According to [6], the pure scale of fraud, embezzlement and corruption perceived in some of the failed government institutions brought into question the reliability and effectiveness of present day operational and compliance control devices and financial reporting in general.

Financial performance is a measure a firm's ability to use assets for revenue generation. Financial performance is a subjective measure of the accountability of an entity for the results of its policies, operations and activities quantified for an identified period in financial terms. Financial performance can be measured 
using ratio analysis that include, profitability ratio, solvency ratio, liquidity ratio, financial efficiency ratio and finally the repayment capacity of an entity for given period. However, Financial performance in the corporate governance arena have been measured in several ways. For example, [7] in a study that analysed the effect of corporate governance on firm performance in Sri Lanka, India used ROE, ROA, and EPS to measure firm performance. On the other hand, [8] in a study all companies quoted at the NSE used return on assets and Tobin $\mathrm{Q}$ ratio. While [2] investigating the effect of corporate governance on financial performance of listed companies in India used ROA, ROE, ROCE and PBT.

\section{Agricultural Sector in Kenya}

In Kenya, agricultural sector is the backbone of the economy. However, only six out of 54 listed companies in the NSE are agricultural. There are six companies currently listed in the NSE are Williamson Tea company, Sasini limited, Limuru Tea, Kapchoria Tea company, Kazuzi Limited and Eaagad limited after Rea Vipingo limited de-listed in 2014. The Capital Markets Act (Cap 485A) provides guidelines on corporate governance practices by public companies in Kenya. The CMA guidelines on corporate governance cover such areas as; the rights of shareholders; equitable treatment of shareholders; role of stakeholders; board structures; disclosure and transparency and board responsibilities. The CMA Code of Best Practice is prescriptive on Board characteristics for companies listed at the Nairobi Securities Exchange (NSE).

\section{Research Problem}

A number of agricultural companies in Kenya have collapsed. However, enough research has not been done on this sector to enlighten corporate issues affecting it. Previous researchers have been concentrating on Banking sector and other service industries thereby ignoring the agricultural sector yet Kenya's economy depends on agriculture. Despite tight regulatory framework, corporate governance continues to weaken in Kenya [8]. According to [9], scandals characterize many companies in Kenya and around the world. Directors have served personal interests instead of serving their shareholders. There is a problem in corporate governance as we have witnessed recently in the banking sector where two banks namely Imperial bank and Chase bank have gone under receivership. Others like Mumias listed agricultural company, Uchumi supermarket and Kenya Airways are struggling to remain in the market by post poor financial results. Their performance have been directly or indirectly castigated by poor corporate governance. The problems of corporate governance in listed agricultural companies has not been exhaustively done.

Empirical studies have demonstrated a link between corporate governance practices and firm performance in emerging markets; however, few researchers have investigated individual countries in depth. [10] examined the impact of corporate governance on performance in Pakistan. Their findings revealed that corporate governance structure influences performance. They advice the regulators to be vigilant and to set different codes for each type of companies. A study by [8] analysed impact of corporate governance on performance of all listed companies in Kenya. However, the study did not assess the effect of corporate governance on performance individual sectors like agriculture. It is due to these research gaps that the study was undertaken to answer the following question; does corporate governance practices influence financial performance of listed agricultural firms in Kenya?

\section{Research Objective}

The research objective of this study was to determine whether corporate governance practices employed by listed agricultural companies in Kenya influence their financial performance.

\section{Empirical Review}

A study by [10] examined the impact of corporate governance on family and nonfamily controlled companies' performance in Pakistan. The sample size of this study is 792 companies listed on Karachi Stock Exchange from 2003 to 2008. The findings revealed that corporate governance structure influences the family and non-family controlled companies' performance. However all corporate governance mechanisms were not significant. The significant variables differ between family and non-family controlled companies. Thus, regulators need to be vigilant that family and non-family controlled companies practice differently and to set different codes for each type of companies.

A study by [11] examined ownership structure, board structure and their relationship performance in public sector companies in Uganda. They study used 85 public sector entities in Uganda. The findings shoe that, CEO duality is not key as far as the performance was concerned. Findings show variance in performance could be explained by ownership structure and board structure. The study concluded that it is necessary to reduce government ownership so as to achieve better performance.

A study by [2] investigated the effect of corporate governance on financial performance in India using 20 listed companies. Various tests such as regression, correlation, t-test and F-test were performed using secondary data for of two years- 2010-11 and 2011-12. The dependent variable were ROA, ROE, ROCE and 
PBT. The independent variables wee employees-related, community-related and environmental dimensions The study also controlled for size of firm. The study found that corporate governance had positive and significant impact on financial performance.

A study by [12] examined the relationship between board size and firm performance. This relationship was tested using the Pareto Approach for Pakistani banking. A sample of 14 listed banks of Pakistan for 20082012 was used. Different models were applied to test the effect of corporate governance practices on bank performance. The results were contradictory with the extant studies on corporate governance variables and firm performance. The foremost finding was that there was significant positive relationship between board size and bank performance. It was concluded that a large board size can enhance the bank performance in Pakistani.

A study by [8] assessed the significance of the board composition, size of the board, proportion of outside directors, proportion of inside directors, and the role of CEO duality on firm performance. All companies quoted at the NSE were analysed for period of four years from 2004 to 2007. The study measured firm performance by the Return on Assets and Tobin Q ratio. This study found that the overall regression models for firm performance for both the Return on Assets and Tobin Q ratio are significant. This implies that the corporate governance variables above were important for firm performance.

A study by [7] analyzed the effect of corporate governance on firm performance in Sri Lanka, India. CEO duality, board Size, and proportion of non-executive directors were used as corporate governance dimensions. ROE, ROA, and EPS were the measures of firm performance used. Data was obtained from the financial reports of 100 quoted companies in the Colombo Stock Exchange for the years 2010-2012. OLS regression findings show that board size was negatively related with firm performance. This implies that small boards are related with higher firm performance, possibly through close supervision management. Moreover, the results show that the separation of the two positions of CEO and chairman has a significant positive effect on the firm performance. However, presences of non-executive directors was not related with firm performance.

A study by [13] examined the effect of corporate governance on the profitability of Indian textile sectors. The data was collected from annual reports of textiles companies for five year from 2009-2010 to 20132014. The profitability was the dependent variable.. Board size, audit committee members, board meetings, non executive directors, directors remunerations were independent variables. Data analysis by was correlation and OLS regression model. A strong positive relationship was observed between director's remuneration and profitability. The Audit Committee members had negative associated with the profitability. The study concluded that board size, board meeting and non executive directors were insignificantly associated with the profitability.

\section{Research Methodology}

A descriptive correlational research design was adopted. The population of this study consisted of 7 agricultural firms listed in the Nairobi Securities Exchange in the period 2012 to 2016. Census was used so all the the firms that were listed in the period were targeted. Secondary data was collected from published audited annual reports and financial statements of these listed agricultural companies. Financial data included statements of financial position, comprehensive income as well as cash flow statements relating to the period under study. Secondary data was collected for the period of five years between 2012 and 2016 for except for Rea Vipingo limited whose data was for 2012 and 2013.

\section{Data Analysis}

Data was analysed using Statistical Package for Social Sciences (SPSS) version 21. Descriptive statistics including mean, standard deviations, minimum and maximum. Tables were used to present the data to enable ease of understanding and analysis. Correlation and multiple regression analysis were used to find out whether the independent variables predicted the given dependent variable. The study used ROE, ROE and debt equity ratio for 5 years for each company as the measure of financial performance. Several studies [7, 8] have used more than one measure of financial performance. For example, [8] used ROA and Tobin Q ratio while [7] used three measure namely ROE, ROA, and EPS.

The regression model treated financial performance as the dependent variable while the independent variables were the board size, board composition, presence of audit committees and independence of board committees. Size of the Board was measured by the number of the board members sitting in a full board meeting, board composition the ratio of executive to non-executive directors, independence of board committees by number of independent directors in the committee and proportion of directors in audit committees to the entire board.

The linear model used was;

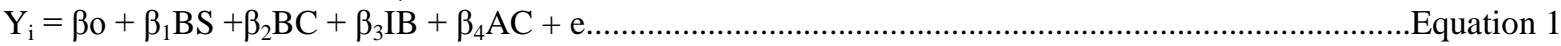

Where: $\mathrm{Y}_{\mathrm{i}}=$ performance $\left(\mathrm{Y}_{1}=\mathrm{ROA} ; \mathrm{Y}_{2}=\mathrm{ROE} ; \mathrm{Y}_{3}=\right.$ Debt Equity Ratio $)$ 
$\beta o=$ Constant of the model

$\beta_{1}$ to $\beta_{4}=$ Regression coefficients

$\mathrm{BS}=$ Board size

$\mathrm{BC}=$ proportion of executive and non-executive board members

$\mathrm{IB}=$ proportion of independence of board members

$\mathrm{AC}=$ proportion of directors in the audit committees

$\mathrm{e}=$ error term

\section{Results and Discussions of Findings}

The data was summarized and descriptive statistics of mean and standard deviation calculated for the respective variables. The resultant mean values of the independent variables were then regressed against the dependent variable. Data analysis was done through Statistical Package for Social Sciences (SPSS) Version 21. Descriptive statistics were done using percentages, means and standard deviations The seven agricultural companies are Williamson Tea company (WT), Sasini limited (SL), Limuru Tea (LT), Rea Vipigo (RV), Kapchoria Tea company (KT), Kazuzi Limited (KL) and Eaagad limited (EL)

Table 1: ROA in Percent

\begin{tabular}{|l|l|l|l|l|l|l|l|l|}
\hline & WT & SL & LT & RV & KT & KL & EL & Mean \\
\hline Mean & 6.96 & 4.73 & 15.59 & 10.64 & 2.69 & 10.99 & -4.67 & 7.15 \\
\hline S. D & 6.60 & 8.00 & 61.30 & 3.78 & 5.37 & 5.07 & 7.14 & 25.80 \\
\hline Min. & -2.65 & -0.75 & -97.93 & 6.69 & -1.11 & 4.44 & -11.82 & -97.93 \\
\hline Max. & 11.79 & 22.46 & 83.37 & 15.67 & 6.48 & 16.88 & $\underline{3.67}$ & $\underline{83.33}$ \\
\hline
\end{tabular}

Table 1 shows that the mean for ROA was 7.15\%. Sasini limited, Eaagad limited and Kapchorua Tea company had below the average ROA. While Limuru tea company had the highest ROA and also the highest standard deviation.

Table 2: ROE in Percent

\begin{tabular}{|l|l|l|l|l|l|l|l|l|}
\hline & WT & SL & LT & RV & KT & KL & EL & Mean \\
\hline Mean & 9.79 & 2.19 & 24.09 & 14.77 & 7.25 & 15.39 & -5.78 & 10.09 \\
\hline Std. Dev. & 9.22 & 2.43 & 152.33 & 4.42 & $\underline{8.05}$ & $\underline{7.43}$ & $\underline{8.7}$ & $\underline{55.78}$ \\
\hline Minimum & -3.45 & $\underline{-1.04}$ & $\underline{-216.34}$ & $\underline{10.42}$ & $\underline{-1.54}$ & $\underline{5.68}$ & $\underline{-14.64}$ & $\underline{-216.34}$ \\
\hline Maximum & $\underline{17.27}$ & $\underline{5.79}$ & $\underline{206.52}$ & $\underline{20.92}$ & $\underline{14.25}$ & $\underline{23.37}$ & $\underline{4.37}$ & $\underline{206.52}$ \\
\hline
\end{tabular}

Table 2 indicates that the mean for ROE was 10.09\%. Sasini limited, Eaagad limited and Kapchorua Tea company had ROE below the average. While Limuru tea company had the highest ROE and also the highest variability.

Table 3: Debt equity ratio

\begin{tabular}{|l|l|l|l|l|l|l|l|l|}
\hline & WT & SL & LT & RV & KT & KL & EL & Mean \\
\hline Mean & 0.37 & 0.27 & 0.72 & 0.41 & 0.39 & 0.39 & 0.25 & 0.40 \\
\hline Std. Dev. & $\underline{0.07}$ & 0.15 & 0.58 & 0.12 & 0.01 & 0.09 & 0.12 & 0.27 \\
\hline Minimum & 0.30 & 0.09 & 0.28 & 0.29 & 0.39 & 0.27 & 0.15 & 0.09 \\
\hline Maximum & 0.46 & 0.42 & 1.48 & 0.56 & 0.40 & $\underline{0.49}$ & $\underline{0.46}$ & $\underline{1.48}$ \\
\hline
\end{tabular}

Table 3 indicates that the mean for debt equity ratio was 40\%. Limuru Tea company and Rea vipingo had debt equity ratio above the average. While Eaagad limited had the lowest debt equity ratio whereas Kapchorua Tea company had lowest variability. 
Effect Of Corporate Governance Practices On Financial Performance Of ...

Table 4: Descriptive statistics on profit after Tax in Kshs. Millions

\begin{tabular}{|c|c|c|c|c|c|c|c|c|}
\hline & WT & SL & LT & RV & KT & KL & EL & Mean \\
\hline Mean & 555.00 & 1183.14 & 33.80 & 288.75 & 51.50 & 382.00 & -21.75 & 259.41 \\
\hline Std. Dev. & 524.22 & 2188.12 & 224.92 & 132.67 & 103.94 & 193.26 & 35.472 & 328.92 \\
\hline Minimum & -227.00 & -67.00 & -331.00 & 153.00 & -22.00 & 160.00 & -59.00 & -331.00 \\
\hline Maximum & 855.00 & 6067.00 & 285.00 & 444.00 & 125.00 & 644.00 & 21.00 & 974.00 \\
\hline
\end{tabular}

Table 4 show that the mean profit after tax was 259.41 millions. Limuru tea company, Kapchorua Tea and Eaagad limited had profit after tax below the average. While Eaagad limited had the lowest profit after tax. Sasini limited had the highest variability.

Table 5: Descriptive statistics on total assets in Kshs. Millions

\begin{tabular}{|l|l|l|l|l|l|l|l|l|}
\hline & WT & SL & LT & RV & KT & KL & EL & $\underline{\text { Mean }}$ \\
\hline Mean & 8,252 & $\underline{18,595}$ & $\underline{269}$ & $\underline{2,642}$ & $\underline{1,955}$ & $\underline{3,428}$ & $\underline{532}$ & $\underline{5,531}$ \\
\hline Std. Dev & 823 & 10,258 & $\underline{88}$ & $\underline{45}$ & $\underline{38}$ & $\underline{354}$ & $\underline{75}$ & $\underline{7,473}$ \\
\hline Minimum & $\underline{7,243}$ & $\underline{8,922}$ & $\underline{158}$ & $\underline{2,248}$ & $\underline{1,928}$ & $\underline{2,853}$ & $\underline{445}$ & $\underline{158}$ \\
\hline Maximum & $\underline{9,184}$ & $\underline{30,851}$ & $\underline{342}$ & $\underline{3,202}$ & $\underline{1,982}$ & $\underline{3,816}$ & $\underline{615}$ & $\underline{30,851}$ \\
\hline
\end{tabular}

Findings in Table 5 depict that the mean total assets was Kshs. 5.531 billions. Williamson Tea company and Sasini limited had total assets above the average. While Limuru Tea company had the lowest total assets. Whereas Sasini limited had highest variability.

Table 6: Descriptive statistics on Total liabilities in Kshs. Millions

\begin{tabular}{|l|l|l|l|l|l|l|l|l|}
\hline & WT & SL & LT & RV & KT & KL & EL & Mean \\
\hline Mean & 2,188 & 2,669 & 109 & 742 & $\underline{51}$ & 938 & 2 & 1,126 \\
\hline Std. Dev. & 157 & 154 & 79 & 51 & 5 & 139 & 411 & 987 \\
\hline Minimum & 1,975 & 2,485 & 38 & 711 & $\underline{547}$ & $\underline{770}$ & $\underline{80}$ & $\underline{38}$ \\
\hline Maximum & 2,315 & 2,857 & $\underline{204}$ & $\underline{819}$ & $\underline{555}$ & $\underline{1111}$ & $\underline{1,007}$ & $\underline{2,857}$ \\
\hline
\end{tabular}

Findings in Table 4.6 depict that the mean total liabilities was Kshs.1.126 billions. Sasini limited had total liabilities above the average. Eaagad limited had the highest variability. While Limuru Tea company had the lowest total liabilities

Table 7: Descriptive statistics on Board Size

\begin{tabular}{|l|l|l|l|l|l|l|l|l|}
\hline & WT & SL & LT & RV & KT & KL & EL & Mean \\
\hline Mean & 7 & 9.14 & 3.00 & 5.00 & 7.50 & $\frac{5.67}{3.00}$ & $\frac{5.75}{2.0}$ \\
\hline Std. Dev. & 0 & 1.46 & 0.00 & 0.00 & 0.71 & 2.58 & 0.00 & 2.44 \\
\hline Minimum & 7 & 7 & 3 & 5 & 7 & 2 & 3 & 2.00 \\
\hline Maximum & 7 & 11 & 3 & 5 & 8 & 8 & 3 & 10.00 \\
\hline
\end{tabular}

The study sought to determine the number of the board of director members. Table 7 indicates that the mean board members was 5.75. Willaimson Tea, Sasini limited and Kapchoria Tea had board sizes above the average. While Limuru Tea company and Eaagad limited had the smallest boards of three and they had violated CMA Act minimum threshold of five directors. Whereas Sasini limited had highest variability.

Table 8: Descriptive statistics on the Board Structure or Composition

\begin{tabular}{|c|c|c|c|c|c|c|c|c|}
\hline & WT & SL & LT & $\mathbf{R V}$ & KT & KL & EL & Mean \\
\hline Mean & 40.00 & 14.08 & 200.00 & 25.00 & 15.48 & 48.89 & 200.00 & 78.21 \\
\hline Std. Dev. & 0.00 & 3.37 & 0.00 & 0.00 & 1.68 & 10.68 & 0.00 & 78.53 \\
\hline Minimum & 40.00 & 11.11 & 200.00 & 25.00 & 14.29 & 33.33 & 200.00 & 11.11 \\
\hline Maximum & 40.00 & 20.00 & 200.00 & 25.00 & 16.67 & 60.00 & 200.00 & 200.00 \\
\hline
\end{tabular}


The study sought to determine the percentage of executive to non-executive director. The CMA Act (2002) recommends at least a third should be non-executive. Table 8 indicates that the mean board structure was 78.21\%. Generally, this is poor board composition. Limuru Tea company and Eaagad limited had board structures where the executive director were double those who non-executive. Whereas Kakuzi limited and Williamson Tea had $48.89 \%$ and $40 \%$ board composition composition respectively. Therefore, onlySasini limited, Rea vipingo and Kapchoria Tea had obeyed the CMA Act.

Table 9: Descriptive statistics on Audit Committees of the Board

\begin{tabular}{|l|l|l|l|l|l|l|l|l|}
\hline & WT & SL & LT & RV & KT & KL & EL & $\frac{\text { Mean }}{2}$ \\
\hline Mean & 2.33 & $\underline{0.00}$ & $\underline{3.00}$ & $\underline{2.00}$ & $\underline{4.00}$ & $\frac{0.00}{2.19}$ \\
\hline Std. Dev. & 0 & $\underline{.516}$ & $\frac{0.00}{3}$ & $\underline{0.000}$ & $\underline{0.000}$ & $\underline{0.00}$ & $\underline{0.00}$ & $\underline{1.55}$ \\
\hline Minimum & 2 & $\underline{0}$ & $\underline{3}$ & $\underline{2}$ & $\underline{4}$ & 0 & 0 \\
\hline Maximum & 2 & 4 & 0 & $\underline{3}$ & $\underline{2}$ & $\underline{4}$ & 0 & 4 \\
\hline
\end{tabular}

The study sought to determine the number of directors in the audit committee. The CMA Act recommends at least 3 independent and non-executive directors who reports directly to the full board. Table 9 indicates that the mean audit committee size was 2.19. Limuru Tea company and Eaagad limited did not board have audit committees. Williamson Tea and Kapchoria Tea company had two directors each. Therefore, Limuru Tea company, Eaagad limited, Kapchoria Tea and Williamson Tea company had violated the CMA Act threshold of 3 members.

Table 10: Proportion of independent directors

\begin{tabular}{|l|l|l|l|l|l|l|l|l|}
\hline & WT & SL & LT & RV & KT & KL & EL & $\underline{\text { Mean }}$ \\
\hline Mean & $\underline{42.86}$ & $\underline{24.67}$ & $\underline{0.00}$ & $\underline{40.00}$ & $\underline{0.00}$ & $\underline{60.62}$ & $\underline{0.00}$ & $\frac{25.62}{290}$ \\
\hline Std. Dev. & $\underline{0.00}$ & $\underline{29.69}$ & $\underline{0.00}$ & $\underline{0.00}$ & $\underline{0.00}$ & $\underline{31.01}$ & $\underline{0.00}$ & $\underline{27.07}$ \\
\hline Minimum & $\underline{42.86}$ & $\underline{10.00}$ & $\underline{0.00}$ & $\underline{40.00}$ & $\underline{0.00}$ & $\underline{33.33}$ & $\underline{0.00}$ & $\underline{0.00}$ \\
\hline Maximum & $\underline{42.86}$ & $\underline{90.91}$ & $\underline{0.00}$ & $\underline{40.00}$ & $\underline{0.00}$ & $\underline{100.00}$ & $\underline{0.00}$ & $\underline{100.00}$ \\
\hline
\end{tabular}

The study sought to determine the proportion of independent directors in the board. The CMA Act (2002) recommends a majority. Table 10 indicates that the mean proportion of independent directors was 25.62\%. Limuru Tea company, Williamson Tea company and Eaagad limited did not independent directors in board. Therefore, only Kakuzi limited had achieved the benchmark set by the CMA Act.

Table 11: Correlation matrix for ROA

\begin{tabular}{|l|l|l|l|l|l|}
\hline & ROA & BS & IB & AC & BC \\
\hline ROA & 1 & & & & \\
\hline BS & -.186 & 1 & & & \\
\hline IB & -.166 & $.523^{* *}$ & 1 & & \\
\hline AC & -.172 & -.025 & $.596^{* *}$ & 1 & \\
\hline BC & .282 & $-.706^{* *}$ & $-.543^{* *}$ & $-.503^{* *}$ & 1 \\
\hline
\end{tabular}

Results in Table 11 show there was weak negative correlation between corporate governance practices and ROA except with Board composition. The highest correlation coefficient is 0.282 indicates weak positive correlation between corporate governance practices and ROA. The highest correlation coefficient is 0.706 between board composition and board size. Since none of these correlation coefficients between the independent variables is greater than 0.8 , there is no multicollinearity. 
Table 12: Correlation matrix for ROE

\begin{tabular}{|l|l|l|l|l|l|}
\hline & ROE & BS & IB & AC & BC \\
\hline ROE & 1 & & & & \\
\hline BS & -.185 & 1 & & & - \\
\hline IB & -.165 & $.523^{* *}$ & 1 & - & - \\
\hline AC & -.172 & -.025 & $.596^{* *}$ & 1 & - \\
\hline BC & .282 & $-.706^{* *}$ & $-.543^{* *}$ & $-.503^{* *}$ & 1 \\
\hline
\end{tabular}

Results in Table 12 show there was weak negative correlation between corporate governance practices and ROE except with Board composition. The highest correlation coefficient is 0.282 indicates weak positive correlation between corporate governance practices and ROE. The highest correlation coefficient is 0.706 between board composition and board size. Since none of these correlation coefficients between the independent variables is greater than 0.8 , there is no multicollinearity.

Reviewing results in Table 11 and 12. corporate gorvernace practices have negative correlation with ROA and ROE. This a similar to a study by [7] which analysed the effect of corporate governance on firm performance in Sri Lanka The study found that board size is negatively related with firm performance. It concluded that small boards are related with higher firm performance, possibly through close supervision management. Whilst a study by [13] examining the effect of corporate governance on the profitability of companies in India found audit committee members had negative associated with the profitability.

Table 13: Correlation matrix for Debt equity ratio

\begin{tabular}{|c|c|c|c|c|c|}
\hline & $\mathrm{DE}$ & BS & IB & $\mathrm{AC}$ & $\mathrm{BC}$ \\
\hline $\mathrm{DE}$ & 1 & & & & \\
\hline$\overline{B S}$ & $.347^{*}$ & 1 & & & \\
\hline IB & $.472^{* *}$ & $.523^{* *}$ & 1 & & \\
\hline$\overline{\mathrm{AC}}$ & -.070 & -.025 & $.596^{* *}$ & 1 & \\
\hline$\overline{\mathrm{BC}}$ & -.119 & $-.706^{* *}$ & $-.543^{* *}$ & $-.503^{* * *}$ & 1 \\
\hline
\end{tabular}

$* * \mathrm{p}<.001, * \mathrm{p}<.05$

Results in Table 13 show there was weak positive correlation between board size and independent board and debt equity ratio while it was negative with with audit committee and board composition. The highest correlation coefficient is 0.472 indicates moderate positive correlation between independent board practice and debt equity ratio. The highest correlation coefficient is 0.706 between board composition and board size. Since none of these correlation coefficients between the independent variables is greater than 0.8 , there is no multicollinearity.

Table 14: Regression Model Summary

\begin{tabular}{|l|l|l|l|}
\hline & ROE & ROA & Debt equity ratio \\
\hline $\mathrm{R}$ & .284 & .284 & .659 \\
\hline $\mathrm{R}^{2}$ & .081 & .081 & .435 \\
\hline Adjusted $\mathrm{R}$ & -.51 & -.051 & .357 \\
\hline Standard error & 36.85998 & 1486.76315 & .34173 \\
\hline
\end{tabular}

Results in Table 13 show the coefficients of determination $\left(\mathrm{R}^{2}\right)$ values are sufficiently low (i.e. less than .50) for ROE and ROA implying low predict power while that for Debt equity ratio is high. The $\mathrm{R}^{2}$ indicates the variation in ROE and ROA due to changes in independent variables. Table 4.13 show that there was a $28.4 \%$ variation in ROE and ROA performance were due to changes in Board size, Board composition, independence of board and audit committees while $65.9 \%$ variation in debt equity ratio were due to changes in Board size, Board composition, independence of board and audit committees. 
Table 15: ANOVA -ROA

\begin{tabular}{|c|c|c|c|c|c|c|}
\hline \multicolumn{2}{|c|}{ Model } & \multirow{2}{*}{$\begin{array}{l}\begin{array}{l}\text { Sum of } \\
\text { Squares }\end{array} \\
3332.998\end{array}$} & \multirow[t]{2}{*}{ df } & \multirow{2}{*}{$\begin{array}{l}\begin{array}{l}\text { Mean } \\
\text { Square }\end{array} \\
833.250\end{array}$} & \multirow{2}{*}{$\begin{array}{l}\mathbf{F} \\
.613\end{array}$} & \multirow{2}{*}{$\begin{array}{l}\text { Sig. } \\
.657^{\mathrm{b}}\end{array}$} \\
\hline & Regression & & & & & \\
\hline \multirow{2}{*}{1} & Residual & 38042.430 & 28 & 1358.658 & & \\
\hline & Total & 41375.428 & 32 & & & \\
\hline \multicolumn{7}{|c|}{ a. Dependent Variable: $\overline{\text { ROE }}$} \\
\hline \multicolumn{7}{|c|}{ b. Predictors: (Constant), AC, BS, IB, BC } \\
\hline
\end{tabular}

Results in Table 14 show the significance of $F$ values is more than $.05(p=.657)$. Thus, the model fit not valid and therefore could not predict ROE significantly.

Table 16: ANOVA -ROE

\begin{tabular}{|c|c|c|c|c|c|c|}
\hline \multicolumn{2}{|c|}{ Model } & Sum of Squares & df & $\begin{array}{l}\text { Mean } \\
\text { Square }\end{array}$ & $\mathbf{F}$ & Sig. \\
\hline \multirow{3}{*}{1} & Regression & 5443239.306 & 4 & 1360809.826 & .616 & $.655^{\mathrm{b}}$ \\
\hline & Residual & 61893010.516 & 28 & 2210464.661 & & \\
\hline & Total & 67336249.822 & 32 & & & \\
\hline
\end{tabular}

a. Dependent Variable: ROA

b. Predictors: (Constant), AC, BS, IB, BC

Results in Table 15 show the significance of $F$ values is more than $.05(p=.655)$. Thus, the model fit not valid and therefore could not predict ROA significantly.

Table 17: ANOVA -Debt Equity Ratio

\begin{tabular}{|c|c|c|c|c|c|c|}
\hline \multicolumn{2}{|c|}{ Model } & $\begin{array}{l}\text { Sum of } \\
\text { Squares }\end{array}$ & df & $\begin{array}{l}\text { Mean } \\
\text { Square }\end{array}$ & F & Sig. \\
\hline \multirow{3}{*}{1} & Regression & 41658.019 & 4 & 10414.505 & 5.435 & $.002^{\mathrm{b}}$ \\
\hline & Residual & 53651.257 & 28 & 1916.116 & & \\
\hline & Total & 95309.276 & 32 & & & \\
\hline
\end{tabular}

a. Dependent Variable: DE

b. Predictors: (Constant), AC, BS, IB, BC

Results in Table 16 show the significance of $F$ values is less than $.05(p=.002)$. Thus, the model fit is good and therefore could predict debt equity ratio with $0.2 \%$ variation significantly. From the Table 4.15 the pvalue was 0.02 which shows that the model was statistically significant.

Table 18: Regression Coefficients

\begin{tabular}{|l|l|l|l|l|l|l|}
\hline & \multicolumn{2}{|c|}{ ROE } & \multicolumn{2}{c|}{ ROA } & Debt equity ratio \\
\hline & Beta & T-value & Beta & T-value & Beta & T values \\
\hline BS & 0.007 & 0.016 & 0.007 & 0.015 & -.356 & -0.975 \\
\hline IB & -0.007 & -0.019 & -0.008 & -0.022 & 1.010 & $3.745^{* *}$ \\
\hline BC & 0.267 & 0.606 & 0.268 & 0.607 & -.219 & -0.656 \\
\hline AC & -0.032 & -0.076 & -0.031 & -0.072 & -.791 & $-2.437^{*}$ \\
\hline$* * \mathrm{p}<001, * \mathrm{p}<.05$
\end{tabular}

Results in Table 17 show all beta coefficients for ROE and ROA are insignificant ( $\mathrm{p}>.05$ ). Thus, corporate governance practices have insignificant effect on ROE and ROA. The p-values for independence of board and size of audit committee are less than .05. Thus, corporate governance practices have significant effect on debt equity ratio. From the Table 17 the regression equation was; Debt equity ratio $=3.745 \mathrm{IB}-2.437 \mathrm{AC}$ where; IB = proportion of Independent board to entire board and AC = proportion of audit committee to entire board. 
This is similar to a study by [10] examining the impact of corporate governance on performance in Pakistan which found all corporate governance mechanisms were not significant. Yet a study by [7] analysing the effect of corporate governance on firm performance in Sri Lanka fund presences of non-executive directors was not related with firm performance. Whilst a study by [13] examining the effect of corporate governance on the profitability of companies in India concluded that board size, board meeting and non-executive directors were insignificantly associated with the profitability.

However, a study by [8] using 5 variable for the all listed companies in NSE found that the overall regression models for firm performance for both the Return on Assets and Tobin Q ratio are significant. The study concluded that the corporate governance practices were important for firm performance. Yet a study by [12] which examined the relationship between board size and firm performance concluded that a large board size can enhance the bank performance in Pakistani.

\section{Summary of Findings}

The research found out that compliance to best practice recommendations by the government and other professional associations in Kenya is quite impressive as is attested to by the statistics analyzed. Out of the seven firms, finding show the firms had above e mean score for ROA and ROE. The risk in debt is minimal because the mean debt equity ratio was $40 \%$ with only two firm having debt equity ratio of above $40 \%$. Only two firms did not report loss in the period of study and profits after tax have wide deviations for all companies. Only companies have total assets of less one billions Kenya shillings whereas five companies owe less than one billions Kenya shillings.

The largest board has 11 directors while the smallest has three. Two companies had violated the CMA Act minimum threshold of five directors. A board composition of at least a third of executive and non-executive directors of diverse skills and expertise is recommended. Results shows board composition is poor and two companies had obeyed the CMA Act with respect to board composition. Three companies did not independent directors in board and only one had achieved the benchmark set by the CMA Act. The audit committee should have diversity in expertise and professions so as to indicate a wealth of knowledge and skills which can result into good decision making thus good financial performance. The CMA Act recommends at least 3 independent and non-executive directors who reports directly to the full board. Two companies did not board have audit committees while another two companies had two. This means four companies had violated the CMA Act threshold of three directors in the audit committee.

Board size, independence of board and audit committee correlated negatively with both, ROA and ROE while board composition related positively. Board size, independence of board correlated positively with debt equity ratio while audit committee and board composition related negatively. The linear regression model for ROA and ROE were invalid while that for debt equity ratio was valid. This means corporate governance practices can only predict debt equity ratio significantly where the the regression's correlation coefficient was strong. While the coefficient for determination is moderate. The debt equity ratio model also had the least standard error for the estimates. Very important, only independence of board and audit committee in the debt equity ratio model significant affect performance.

\section{Conclusions of the Study}

Most agricultural firm have not adhered to the rules and guidelines issued by CMA. Corporate governance practices lead to reduced debt related risks. The valid model only moderately explains the variations in performance of the firms due to changes in Board size, Board composition, independence of board committees and proportion of audit committee. This answers to the objective of the study and confirms that corporate governance practices employed by listed agricultural companies in Kenya influence their financial performance.

\section{Recommendations}

The study recommends among other things that the government ought to enforce the measures it has laid down on corporate governance to ensure public organizations are following them. The concerned ministries should also be keen in the supervisory role through the relevant committees to ensure that all regulations are enforced as required. Number of independent directors in board committees should also be maintained at above 3 as only about half of the corporations were in compliance. More professional experts should be included in the boards to bring in diverse experiences and different ways of doing things. This would bring favourable outlook to the firms which can be of paramount importance when seeking international financial grants, debts and business partnerships. 


\section{References}

[1]. Dibra, R. (2016). Corporate governance failure: The case of Enron. European Scientific Journal June 2016 edition vol.12, No.16 12 (16), 283-291.

[2]. Aggarwal, P. (2013). Impact of corporate governance on corporate financial performance. Journal of Business and Management (IOSR-JBM) , $13(1), 1-5$.

[3]. Padachi, K., Urdhin R, H. \& Ramen M. (2016). Assessing corporate governance practices of Mauritian companies. International Journal of Accounting and Financial Reporting , 6 (1).

[4]. Gompers, P. and Metrick, A. (2003). Corporate governance and equity prices. Quarterly Journal of Economics, 118.107-155.

[5]. Carcello, J.V. and Neal, T.L. (2011). Audit committee independence and disclosure: choice for financially distressed firms. An International Review, 11.289-299.

[6]. Ikiara, M (2010). Should kenya revert back to price control? Kenya Institute for Public Research and Analysis (KIPPRA). Monthly bulletin, October, 2010 Issue, Nairobi.

[7]. Azeez, A. (2015). Corporate governance and firm performance: Evidence from Sri Lanka. Journal of Finance and Bank Management , 3 (1), 180-189.

[8]. Aduda, J., Chogii, R., \& Magutu, P. O. (2013). An empirical test of competing corporate governance theories on the performance of firms listed at the nairobi securities exchange. European Scientific Journal , 9 (13).

[9]. Muriithi, A.M., (2004). The relationship between corporate governance mechanisms and performance of firms quoted on the Nairobi stock exchange. Unpublished MBA project, University of Nairobi

[10]. Yasser, Q. R. (2011). Corporate governance and performance: An analysis of Pakistani listed firms. Global Journal of Management and Business Research, 11 (11).

[11]. Tusiime, I., Nkundabanyanga, S. K., \& Nkote, I. N. (2011). Corporate governance: ownership structure, board structure and performance of public sector entities. Journal of Public Administration and Policy Research, 3 (9), 250-260.

[12]. Malik, M., Wan, D., Ahmad, M. I., Naseem, M., \& Rehman, R. (2014). Role of board size in corporate governance and firm performance applying pareto approach;Is it cultural phenomena? The Journal of Applied Business Research, 30 (5), $1395-1407$.

[13]. Narwal, K. P., \& Jindal, S. (2015). The impact of corporate governance on the profitability: An empirical study of Indian textile industry. International Journal of Research in Management, Science \& Technology , 3 (2). 